\title{
Shareholder Wealth Effects of CEO Succession
}

\author{
Kevin Banning \\ Auburn University Montgomery, Montgomery, USA \\ Email: kbanning@aum.edu \\ Received August $4^{\text {th }}, 2013$; revised September $4^{\text {th }}, 2013$; accepted September $13^{\text {th }}, 2013$ \\ Copyright (C) 2013 Kevin Banning. This is an open access article distributed under the Creative Commons Attribution License, which \\ permits unrestricted use, distribution, and reproduction in any medium, provided the original work is properly cited.
}

\begin{abstract}
Companies often dismiss their chief executive officers (CEOs) when financial performance falters. This study examines why, despite the positive stock market effects, the replacement of the CEO often does little to change a company's financial performance. Thanks to the agency arrangements in some companies, new CEOs are able to negotiate favorable contracts which benefit the CEO rather than the shareholders. In a sample of 140 publicly-traded firms, we found that compensation systems for new CEOs differed as a function of institutional ownership, with total executive compensation higher and compensation risk lower in firms with lower levels of institutional ownership. Financial performance was also weaker in firms with less institutional ownership.
\end{abstract}

Keywords: CEO Compensation; Institutional Ownership

\section{Introduction}

Previous research has identified several causes of CEO turnover, such as mergers and acquisitions [1], but poor firm financial performance is the most common reason [2]. When a firm replaces its CEO because of poor financial results, there are positive consequences for financial markets, and more so if the new CEO comes from outside the firm [3]. The consequence of CEO succession for company financial performance, however, is more ambiguous than the effect on financial markets. While there is some evidence that replacing a CEO has positive implications for firm performance [4], there is also evidence that CEO turnover is associated with performance declines [5]. Other studies suggest that instead of improving financial performance, CEO succession has often had no relationship to company performance [6]. The presence of institutional owners, who might serve as effective monitors of new CEOs, could explain the mixed empirical results concerning the consequences of executive succession.

Replacing the CEO when firm financial performance is lacking creates some confusion for equity owners. There is some evidence the board of directors will grant significant decision autonomy to new CEOs, which can lead to significant change, regardless of whether the incoming chief executive came from inside or outside the company $[7,8]$. However it is also the case that because the effects of succession on financial performance are mixed, and the changes initiated by new CEOs may or may not lead to improved company performance, the objective of changes initiated by new CEOs may be to protect their positions of power in the organization [9].

New CEOs who fail to deliver strong or improved financial performance are vulnerable throughout their first few years on the job [10], and it would be rational for them to fortify their positions after appointment, regardless of the circumstances of the succession. Because executives who serve on the firm's own board are known to contest the new CEO [10], new chief executives have strong incentives to solidify their positions if post-succession financial performance is unimproved. Consequently a new CEO has both the incentive, because of contests among board members, and the opportunity, thanks to a brief "honeymoon period" associated with succession, to arrange an attractive agency contract during the transition.

The agency contract specifies the relationship between a CEO and board of directors. An agency contract will include how the CEO will be monitored and how the CEO will earn his or her compensation [11]. Because there are too many unknowable contingencies, perfect and completely specified contracts are not feasible, resulting in a "relational contract" [12]. Relational contracts are necessarily ambiguous, and could result in some problems relevant to how new CEOs could entrench themselves after succession. One possibility is 
opportunistic behavior, arising from private information, moral hazard, or adverse selection, throughout the contract negotiations. A new CEO could negotiate terms more favorable to him or her because of undisclosed knowledge. Another possibility is post-contractual opportunism, where a new CEO takes advantage of any ambiguities in the contract, because there are many unanticipated contingencies. Such opportunism seems especially likely when the board does not adequately monitor the CEO.

There is some utility in exploring how the incentive structure differs after succession as a way to understand how the new CEO could strengthen his or her position. For example, when there are some equity holders, such as institutional owners who control large enough blocks of stock to influence management, it seems likely that the agency contract will be more favorable to the board of directors. The greater oversight by institutional owners could result in lower levels of CEO control as might be seen in more effective compensation contracting and incentive alignment and potentially stronger firm performance.

\section{Agency Theory in Organizations}

When viewed through an agency framework, shareholders of public companies contract with managers to act on their behalf, and thus delegate to managers the ability to utilize company resources. Because both the shareholders and managers are thought to be rational, the owners must devise ways to effectively supervise the actions of managers. This supervision typically occurs through the contract which specifies how managers will be monitored or share risks with owners, and effectively aligning owners' incentives for success with managers pay, with tools like performance-contingent compensation. When well constructed and executed, monitoring and incentive alignment support strategic choices which benefit both shareholders and managers.

One solution to the agency problem in organizations is monitoring by individual owners. Individual owners often own too small a position or are otherwise unable or unwilling to carefully monitor managers of companies in which they have ownership [12]. Some researchers (e.g., [13]) have observed that institutional owners pay more attention to managerial decisions in the firm because the decisions and consequent company performance are critical to their financial holdings. Consequently when those institutional owners act in ways likely to be beneficial to shareholders, markets react positively [14-16].

While it is clear that there are positive, stock-market effects associated with activism by institutional investors, this activism has produced less consistently positive results with respect to a firm's financial performance, but the finding that performance improvements are associ- ated with investor activism is more common than not [17]. With the generally positive performance effects associated with institutional ownership, there may be other consequences of these owners on outcomes favored by shareholders, and one such outcome is CEO compensation.

\subsection{Creating Incentive Alignment}

Agency theory suggests that a new CEO will attempt to negotiate both more total pay and a smaller performance-contingent component of pay than the predecessor CEO [18], and these conditions are more likely to be granted in the absence of institutional owners. Previous research suggests CEO pay for incumbent CEOs will be lower overall and favor performance-contingent forms of pay when the proportion of institutional investors is higher [19]. Similarly previous research suggests that new CEOs receive compensation packages favoring incentive pay instead of guaranteed forms of compensation [8], but whether the presence of institutional ownership affects the compensation structure has yet to be tested with the compensation of new CEOs.

There are impediments to proper management control in modern corporations, as well as reduced incentives for monitoring by singular, individual owners, and consequently a new CEO could negotiate a compensation contract with more total pay and less risk. The greater levels of total compensation and their smaller proportions of performance-contingent pay are negotiated with the board upon succession. This kind of contract, highly favorable to the incoming CEO, is possible because of the relative weakness of managerial oversight in firms with no strong institutional investors. Any weakness in managerial oversight might be exploited at the time of succession, and the new CEO may achieve an attractive compensation package.

H1: The level of post-succession CEO compensation will be greater in firms with lower institutional holdings.

$\mathrm{H} 2$ : The level of post-succession CEO compensation risk will be smaller in firms with lower institutional holdings.

\subsection{Performance and CEO Succession}

Improved firm-financial performance constitutes the most effective defense strategy for new CEOs, and better financial results would reduce any vulnerability to other managers who serve on the board of directors [10]. There is likely to be some risk of dismissal for a new CEO whose appointment follows poor financial performance. It is reasonable to expect new CEOs in firms lacking effective institutional owners to negotiate contracts with strong defensive mechanisms, and that such arrangements could harm firm performance. Several studies 
show that compensation strategies favoring the CEO tend to be more common in firms lacking effective owneroversight. Similarly, compensation contracts which are structured to de-couple CEO pay from firm performance are associated with decreased financial performance $[8,20]$. Thus, new CEOs in firms with less oversight by institutional owners might have fewer decision constraints than CEOs in firms with effective institutional oversight, and financial performance could suffer.

H3: Lower post-succession financial performance is associated with lower institutional holdings.

\section{Method}

The COMPUSTAT database provided the financial data and succession events were identified in the Wall Street Journal. Initially there were 157 publicly-traded firms experiencing a single succession event during the event period from 2004 to 2008. At five years, the succession-event window was short enough to attribute effects to the new CEO and not to exogenous events, yet long enough to capture enough succession events for statistical purposes. No firms experiencing multiple succession events during the five years, or firms with a CEO succession in the four years immediately preceding the window, or in the year following the window were included. Including companies with multiple successions, with the associated negations of the compensation contracts, would have unnecessarily muddled the analysis and hypothesis tests. Ultimately there were 140 firms across the five years with fully usable data. Using a fixed-effects specification, where a dummy variable represents the year of the succession event to test the hypotheses, permitted robust testing but was simple to operationalize.

\subsection{Dependent Variables}

The first dependant variable, total CEO compensation, was determined from proxy statements for the year following appointment. Total CEO compensation was comprised of all forms of pay reported in the proxy statement, including the Securities and Exchange Commission (SEC) estimate of the present value of stock options received [19]. Despite the difficulty in estimating the present value of stock options, the nearly ubiquitous use of stock options as a large part of the total CEO compensation package justifies their inclusion. The second dependent variable is a measure of compensation risk that is computed as the proportion of total pay that is performance contingent [21]. The performance measure uses return on investment, and is measured in both the year before and year after the succession event. The value from the year before the succession event is used as a control in the regressions, while the post-succession performance serves as the third dependent variable.
All three dependent variables are adjusted for mean values of their corresponding four-digit SIC industry for the first full year following the succession event. The resulting dependent variable for each observation is the observed value minus the industry mean. In a conceptual sense, correcting the observed-value of each firm's total compensation and compensation risk with the mean of the relevant industry creates a value of each dependent variable that controls for any industry-effect. Thus in the case of Total CEO Compensation, positive differences indicate that the CEO for that firm received more than the industry average total pay, and negative differences indicate that the firm's CEO received total pay less than the relevant industry average. The computation for compensation risk and for firm performance works in the same way. This method permits controlling for industry effects in the regression without the corresponding loss of degrees of freedom [22].

\subsection{Independent and Control Variables}

This research addresses the question of whether a sufficiently powerful institutional owner affects the negotiated agency contract for a new CEO and if there is a financial performance effect. The agency contract, including the compensation component, would be expected to differ in firms where the CEO exercised more control relative to the board of directors, which represents owners. Researchers seem to agree that effective oversight of managers is associated with several important consequences [9,23], but there is less consensus as to how to operationalize the influence of institutional owners. This paper uses an institutional ownership measure, after Hadani [17], which takes the percentage of outstanding shares held by the single largest institutional owner. The measure has gained currency based on earlier findings suggesting that only the largest institutional owner would likely possess any information advantage [24].

The influence exercised by institutional owners is only possible reason that compensation contracts for CEOs might differ among firms. There are other firm-specific variables that might affect the contract, such as the size of the company, whether the new CEO came from within the firm, and the conditions under which the previous CEO exited the position. These influences are treated as control variables.

Size. Firm size is operationalized as the natural log of annual revenues reported for the first full year of the successor CEO's tenure.

Successor origin. The new CEO's origin is determined by the last employer prior to becoming the CEO at the focal firm $[25,26]$. If that position was held anywhere other than the focal firm or its subsidiaries, successor origin was one. If the successor CEO was promoted from within the firm or any of its subsidiaries, successor origin 
was zero.

Predecessor disposition. There is also the question of the circumstances of the succession. In assessing the predecessor's disposition in text sources, such as the company proxy statement and the Wall Street Journal, if these were clear the predecessor had voluntarily retired, died, or had voluntarily taken another position, or if it was unclear despite multiple sources, this variable was coded as zero. Only if it was clear that the predecessor was forced to resign or retire, this variable was coded as one.

Lagged performance. Pre-succession firm performance is measured as described above as the firm minus the industry average of the company's return on investment in the last full year preceding the succession event.

Pooled panel year. The data cover a five-year span so the specification used a control variable to capture any unique variance for a particular year in the regression specification.

\subsection{Analysis}

The hypotheses were tested in three pooled regression analyses. The first specification regressed total CEO compensation on the independent and control variables, while the second specification regressed compensation risk, which is the ratio of performance-contingent pay to total pay earned in the first full year after succession, on the same set of independent and control variables. The third specification regressed post-succession firm performance on the independent and control variables.

\subsection{Results}

Descriptive statistics and intercorrelations for the study variables appear in Table 1. Only standardized regression coefficients are reported in the tables for the sake of comparability.

Compensation effects. The regression results for total CEO compensation appear in Table 2. Hypothesis 1, which predicted that the level of total CEO pay would be higher in firms with lower levels of institutional ownership, was supported. Higher levels of CEO compensation were also associated with pre-succession firm performance.

The regression results for compensation risk also appear in Table 2. Hypothesis 2, which predicted that the level of CEO compensation risk would be lower in firms with lower levels of institutional ownership, was supported. When the predecessor CEO was forced out, pay risk was also higher.

Firm performance effects. Regression results for post-succession firm performance appear in Table 2. Hypothesis 3, which predicted that firms with lower levels of institutional ownership would experience lower levels of post-succession financial performance, was supported. Financial performance was also lower if the successor CEO originated from a position outside the firm.

\section{Discussion}

This research suggests that the influence of institutional owners matters to the nature and consequences of the agency contract that is negotiated with new CEOs. It appears that new CEOs who face relatively weaker institutional-investor oversight are able to negotiate more favorable compensation contracts, in terms of both size and risk. Though there are potentially many circumstances which would permit a new CEO to strike a more favorable compensation contract, a lack of institutional ownership appears to matter a great deal. It is important for new CEOs to negotiate an attractive compensation package, because in their early years as chief executive they are subject to competition from their internal colleagues on the board of directors [10].

Other than the influence of an institutional owner and the predecessor's involuntary dismissal, compensation contracts did not seem to vary based on the circumstances surrounding the succession events. In terms of company financial performance, only influence of an

Table 1. Descriptive statistics and intercorrelations.

\begin{tabular}{|c|c|c|c|c|c|c|c|c|c|}
\hline \{PRIVATE $\}$ Variable & Mean & S.D. & 1 & 2 & 3 & 4 & 5 & 6 & 7 \\
\hline 1. Firm size & 3.03 & 1.51 & & & & & & & \\
\hline 2. Lagged performance & 4.11 & 5.10 & 0.06 & & & & & & \\
\hline 3. Origin & 0.80 & 0.12 & -0.03 & -0.04 & & & & & \\
\hline 4. Disposition & 0.42 & 0.46 & 0.03 & -0.16 & $0.19^{*}$ & & & & \\
\hline 5. Total compensation & 12.4 & 1.36 & $0.38^{* *}$ & 0.02 & 0.14 & 0.03 & & & \\
\hline 6. Compensation risk & 0.69 & 0.25 & 0.12 & 0.17 & -0.05 & 0.09 & $0.73^{* *}$ & & \\
\hline 7. Post performance & 4.41 & 4.93 & 0.10 & $0.65^{* *}$ & -0.02 & $-0.21^{*}$ & 0.14 & 0.15 & \\
\hline 8. Institutional owner & 0.10 & 0.04 & $-0.18^{*}$ & 0.03 & 0.08 & 0.11 & $-0.27^{*}$ & $0.19^{*}$ & $0.26^{*}$ \\
\hline
\end{tabular}

Note: ${ }^{*} \mathrm{p}<0.05{ }^{* *} \mathrm{p}<0.01$. 
Table 2. Regression results.

\begin{tabular}{cccccccc}
\hline & \multicolumn{2}{c}{ Total compensation } & \multicolumn{2}{c}{ Compensation risk } & \multicolumn{2}{c}{ Post performance } \\
\hline \{PRIVATE & \multicolumn{2}{c}{$\beta$} & \multicolumn{2}{c}{$\boldsymbol{\beta}$} & \multicolumn{2}{c}{$\beta$} \\
\hline Firm size & $0.389^{* *}$ & 0.351 & -0.131 & 0.047 & 0.092 & 0.378 \\
Lagged performance & $0.162^{*}$ & 0.278 & 0.058 & 0.202 & $0.301^{* *}$ & 0.216 \\
Origin & -0.006 & 0.054 & 0.029 & 0.001 & $-0.174^{*}$ & 0.037 \\
Disposition & -0.050 & 0.125 & $0.156^{*}$ & 0.023 & -0.108 & 0.094 \\
Institutional owner & $-0.194^{*}$ & 0.069 & $0.207^{*}$ & 0.182 & $0.286^{*}$ & 0.255 \\
\hline
\end{tabular}

institutional owner and successor CEOs from outside the firm were significant influences. Stronger financial performance was associated with greater institutional investtor influence, while outside successor CEOs were associated with worse financial performance post-succession.

\subsection{The Effects of Institutional Ownership}

The ways in which new CEOs protect their positions appears to differ in firms based on institutional ownership. CEOs in firms with lower levels of institutionalowner influence were able to achieve less compensation risk than new CEOs in firms with higher levels of influence exercised by institutional owners. These differences in compensation and risk-sharing may account in part for the finding that firms lacking significant institutional ownership do not perform as well as those featuring more institutional ownership, a result consistent with other work that shows that greater institutional ownership is associated with better financial performance [17].

The compensation contract, and in particular the arrangements with respect to how contingent pay is earned, is the primary means shareholders have to align managers' interests with their own. CEOs in firms with less significant institutional ownership appear to receive higher pay and less compensation risk in their negotiated contracts, while successor CEOs in firms with significant institutional ownership experience higher compensation risk. These results suggest managers in firms with low levels of institutional have more influence over the structure and magnitude of their pay, and thus the results are consistent with previous research [20].

Though no direct effects were tested, it may be that the negotiated agency contract impacts the firm's financial performance. In firms with less institutional ownership, where the new CEO may have more influence relative to the board of directors, financial performance is lower than in firms with significant institutional ownership. The overall results suggest that the relatively greater influence of the new CEO under low levels of institutional ownership, as reflected in the terms of the compensation contract negotiated at succession, is one possible reason for the positive association of institutional ownership and financial performance.

\subsection{Negotiated Compensation Terms and Performance}

Though institutional owners appear to influence the compensation terms of the agency-contract negotiated with the board of and the incoming CEO, such that when institutional ownership is small the successor CEO captures a more favorable compensation contract, at least one other factor during succession seems to impact performance as well. The disposition of the previous CEO seems to have some effect on the compensation arrangements. New CEOs who followed one who was dismissed received proportionally more pay which was performance contingent, shifting more of the firm's future performance risk to the new CEO. Compensation terms shifting pay risk to the new CEO represent a reasonable response by firms that have dismissed their previous chief executive, because increased pay-risk signals the board's demand for better future performance.

Though not significant to compensation, whether the new chief executive came from within the firm seems to matter to financial performance. These results contradict previous evidence suggesting that the successor CEO's origin, whether from inside or outside the company, has no effect on post-succession firm performance [26]. Future research that takes into account the social networks of the departing CEO, such as proposed by Cao et al. [27], might further elaborate these results.

Ultimately, the compensation contract terms seem to depend on the interplay between an incoming CEO, institutional owners, and the board of directors. The directors appear to create terms more favorable to shareholders when institutional owners have more influence on the firm. When managers exercise more control, however, the evidence suggests that shareholder interests may be traded for managerial compensation. Firm performance following succession may thus depend more on who controls the contracting process than on other characteristics of the new CEO.

\section{REFERENCES}

[1] J. P. Walsh, "Top Management Turnover Following Mergers and Acquisitions," Strategic Management Jour- 
nal, Vol. 9, No. 3, 1988, pp. 173-183. http://dx.doi.org/10.1002/smj.4250090207

[2] P. H. Furtado and V. Karan, "Causes, Consequences, and Shareholder Wealth Effects of Management Turnover: A Review of the Empirical Evidence," Financial Management, Vol. 19, No. 2, 1990, pp. 60-75.

http://dx.doi.org/10.2307/3665635

[3] W. Davidson, D. Worrell and L. Cheng, "Key Executive Succession and Stockholder Wealth: The Influence of Successor's Origin, Position, and Age," Journal of Management, Vol. 16, 1990, pp. 647-664. http://dx.doi.org/10.1177/014920639001600309

[4] E. He, D.W. Sommer and X. Xie, "The Impact of CEO Turnover on Property-Liability Insurer Performance," Journal of Risk and Insurance, Vol. 78, 2011, pp. 583-608.

[5] J. H. Evans, N. J. Nagarajan and J. Schloetzer, "CEO Turnover and Retention Light: Retaining Former CEOs on the Board," Journal of Accounting Research, Vol. 48, 2010, pp. 1015-1047. http://dx.doi.org/10.1111/j.1475-679X.2010.00383.x

[6] E. C. Chang and S. M. Wong, "Governance with Multiple Objectives: Evidence from Top Executive Turnover in China," Journal of Corporate Finance, Vol. 15, No. 2, 2009, pp. 230-244. http://dx.doi.org/10.1016/j.jcorpfin.2008.10.003

[7] L. E. Greiner and A. Bhambri, "New CEO Intervention and Dynamics of Deliberate Strategic Change," Strategic Management Journal, Vol. 10, 1989, pp. 67-87. http://dx.doi.org/10.1002/smj.4250100707

[8] D. Blackwell, D. Dudney and K. Farrell, "Changes In CEO Compensation Structure and the Impact on Firm Performance Following CEO Turnover," Review of Quantitative Finance \& Accounting, Vol. 29, No. 3, 2007, pp. 315-338.

http://dx.doi.org/10.1007/s11156-007-0034-y

[9] J. Pfeffer, "Power In Organizations," Pitman Publishing, Marshfield, 1981.

[10] W. Ocasio, "Political Dynamics and the Circulation of Power: CEO Succession in US Industrial Corporations," Administrative Science Quarterly, Vol. 39, No. 2, 1994, pp. 285-312. http://dx.doi.org/10.2307/2393237

[11] M. C. Jensen, "Symposium on the Market for Corporate Control: The Scientific Evidence," Journal of Financial Economics, Vol. 11, No. 4, 1983, p. 3. http://dx.doi.org/10.1016/0304-405X(83)90003-X

[12] P. Milgrom and J. Roberts, "Economics, Organization and Management," Prentice Hall, Englewood Cliffs, 1992.

[13] S. Schwab and R. Thomas, "Realigning Corporate Governance: Shareholder Activism by Labor Unions," Michigan Law Review, Vol. 96, pp. 1018-1155. http://dx.doi.org/10.2307/1290082

[14] S. Dasgupta and N. Vikram, "Tender Offers, Proxy Contests, and Large-Shareholder Activism," Journal of Economics and Management Strategy, Vol. 6, No. 4, 1997 , pp. 787-820. http://dx.doi.org/10.1162/105864097567264

[15] S. L. Gillan and L. T. Starks, "Corporate Governance, Corporate Ownership, and the Role of Institutional Investors: A Global Perspective," Journal of Applied Fi- nance, Vol. 13, No. 2, 2003, pp. 4-22.

[16] R. Marens, "Waiting for the North to Rise: Revisiting Barber and Rifkin after a Generation of Union Financial Activism in the US," Journal of Business Ethics, Vol. 52, No. 1, 2004, pp. 109-123. http://dx.doi.org/10.1023/B:BUSI.0000033111.06997.dc

[17] M. Hadani, M. Goranova and R. Kahn, "Institutional Investors, Shareholder Activism, and Earnings Management," Journal of Business Research, Vol. 64, No. 12, 2011, pp. 1352-1360.

http://dx.doi.org/10.1016/j.jbusres.2010.12.004

[18] M. Harris and A. Raviv, "Optimal Incentive Contracts with Imperfect Information," Journal of Economic Theory, Vol. 20, 1979, pp. 231-259.

http://dx.doi.org/10.1016/0022-0531(79)90073-5

[19] P. David, R. Kochhar and E. Levitas, "The Effect of Institutional Investors on the Level and Mix of CEO Compensation," Academy of Management Journal, Vol. 41, No. 2, 1998, pp.200-208 http://dx.doi.org/10.2307/257102

[20] H. L. Tosi and L. R. Gomez-Mejia, "Compensation Monitoring And Firm Performance," Academy Of Management Journal, Vol. 37, No. 4, 1994, pp. 1002-1016. http://dx.doi.org/10.2307/256609

[21] J. D. Westphal and E. J. Zajac, "Defections from the Inner Circle: Social Exchange, Reciprocity, and the Diffusion of Board Independence in US Corporations," $A d$ ministrative Science Quarterly, Vol. 42, No. 1, 1997, pp. 161-183. http://dx.doi.org/10.2307/2393812

[22] R. E. Hoskisson, R. A. Johnson and D. D. Moesel, "Corporate Divestiture Intensity in Restructuring Firms: Effects of Governance, Strategy, and Performance," Academy of Management Journal, Vol. 37, No. 5, 1994, pp. 1207-1251. http://dx.doi.org/10.2307/256671

[23] S. Finkelstein and D. C. Hambrick, "Chief Executive Compensation: A Study of the Intersection of Markets and Political Processes," Strategic Management Journal, Vol. 10, No. 2, 1989, pp. 121-134. http://dx.doi.org/10.1002/smj.4250100203

[24] K. Schnatterly, K. Shaw and W. W. Jennings, "Information Advantages of Large Institutional Owners," Strategic Management Journal, Vol. 29, No. 2, 2008, pp. 219-227. http://dx.doi.org/10.1002/smj.654

[25] D. R. Dalton and I. F. Kesner, "Organizational Performance as an Antecedent of Inside/Outside Chief Executive Succession: An Empirical Assessment," Academy of Management Journal, Vol. 28, No. 4, 1985, pp. 749-762. http://dx.doi.org/10.2307/256235

[26] A. Karaevli, "Performance Consequences of New CEO 'Outsiderness': Moderating Effects of Pre- and PostSuccession Contexts," Strategic Management Journal, Vol. 28, No. 6, 2007, pp. 681-706. http://dx.doi.org/10.1002/smj.589

[27] Q. Cao, L. M. Maruping and R. Takeuchi, "Disentangling the Effects of CEO Turnover and Succession on Organizational Capabilities: A Social Network Perspective," Organization Science, Vol. 17, No. 5, 2006, pp. 563-576. http://dx.doi.org/10.1287/orsc.1060.0201 